\title{
THREE APPROACHES TO THE SOCIOLOGICAL STUDY OF THE SOCIAL WELL-BEING ${ }^{2}$
}

\begin{abstract}
The globalizing and diversifying world demands from sociology to constantly redefine its boundaries, especially with psychology. It is also necessary to identify the specifics of the sociological interest to such a psychological issue as mental health. This can be done by limiting the focus of the sociological study to the social well-being that can be 'measured' in three perspectives: first, identification of value orientations; second, description of fears that prevail in society or its particular groups; and, third, attempts to measure the level of happiness, its factors and components in terms of their 'size', changes and sustainability at the national level and in the comparative perspective. The article presents some empirical examples of all three sociological 'dimensions' of the social wellbeing.
\end{abstract}

Keywords:: social well-being; value orientations; fears; happiness; survey.

\section{Introduction}

Sociology is a quite young discipline, which determined its interdisciplinarity due to the fact that 'social order' as a key and essential concept of sociology has a much longer history than sociology itself and was first considered in the so-called "Hobbes' question" (Filippov, 2017), and at the same time the strained relationship of sociology with other social sciences that claim to study exactly the same phenomena and aspects of social reality such as 'social development', 'conflicts', 'justice/injustice' and many others. In particular, these terms refer to political issues, which explains the 'politicization' of sociology and everlasting disputes of scholars on whether it is correct to speak of political sociology as a branch of sociology or to leave all political issues only to political science. Such disputes are hardly to be solved for the concepts 'social order', 'progress', 'justice', etc. form the eternal questions of sociology (and social sciences) even under its current harsh criticism (see, e.g.: Flyvbjerg, 2001). Such disputes also form eternal (though rather imaginary)

1 irina.trotsuk@yandex.ru

2 The research was supported by the Russian Foundation for Basic Research. The project No. 18011-00993 "Happiness as an interdisciplinary construct: Variations of sociological conceptualization and operationalization". 
confrontations of 'progressist' and 'conservative' traditions and social-constructivist and universalist theories, and between advocates of legal or normal/normative conceptions of social order (see, e.g.: Abrutyn, Carter, 2014) and their critics arguing that today we live under 'anormative' bureaucratic regulation that responds faster to new social changes but ignores traditional concerns about legitimacy (see, e.g.: Archer, 2018; Turner, 2010).

Thus, sociology and political science have many common issues, and there is an obvious trend to politicization of sociology for governments and elites strive to control sociological work due to the persisting global divisions of West and East, North and South, classes, gender, and race, and to the new divides such as a digital divide, which makes social order unstable and unpredictable. Certainly, a sociologist "should have a notion of what a good society should be and what are the political objectives to achieve it. But in doing research one should have a necessary detachment from the social problems... We all have our own value premises, preferences, prejudices... But in doing serious sociological work, one must keep in mind that we need some critical detachment. Otherwise, one may try to manipulate data in order to pursue a political objective goals, to ignore contrary evidence" (Martinelli, 2018, p. 24).

This is an obvious requirement if we consider the relationship of sociology and political science, but the same applies to the relationship of sociology and (social) psychology, which is rarely considered not too mentioned its problematization. Thus, the above statement can be easily rephrased for the micro-level of analysis, i.e. in the social-psychological perspective. A sociologist should have a notion of what a good person should be; but in doing research one should have a necessary emotional detachment from the social problems he or she is analyzing and from the real people he or she is communicating with. We all have our personal value premises, preferences, prejudices, and emotions; but in doing serious sociological work, one must keep in mind that we need some critical and emotional detachment. Otherwise, one may try to manipulate data in order to pursue personal goals, to ignore contrary evidence and to prefer evidence that supports one's relations with respondents and corresponds to the personal worldview.

Today we live in the world with the growing scale and severity of mental health problems, especially in post-conflict and transitional societies, and with the global increase of the number of alcohol and other psychoactive substances users, suicides, depression and anxiety-depressive disorders, etc. This makes sociologists consulted about state strategies for prevention of drug and alcohol use, for strengthening social-cultural factors of mental health, for developing a social environment tolerant/friendly to people with mental disorders, and so on (for instance, one can look through the official websites of the Russian Government, some Russian ministries and other state and regional authorities to find out that many of them have special analytical departments that conduct or order sociological surveys to find out the public opinion on the planned decisions and changes). This also makes sociologists believe that they have the right to make expert judgements about the issues that previously were considered the domain of (social) psychology. However, such a belief can be delusive and lead to serious mistakes for sociologists have never studied and will not study in the future mental health, and the confusions here are determined by an extreme popularity of the term 'mentality' with a very confusing and ambiguous definition, and by the growing sociological interest to the issues of self-identification in both cognitive and affective terms. 
The second foundation of 'psychologization' of sociology is a logical consequence and extension of a number of 'turns' in social sciences and humanities in the $20^{\text {th }}$ century. The 'linguistic turn' suggested interpretation of social facts as representations of discursive mechanisms and of human life as an 'auto-linguistic phenomenon' (Löfgren, 1981). The 'narrative turn' underlined the 'narrative nature' of all texts including personal and group biographies (see, e.g.: Franzosi, 1998; Fraser, 2004) within the discourses constructing social reality. The 'visual turn' emphasized the importance of visual 'dimension' of personal and social life due to the omnipresence of visual images and "establishment of the 'chronic voyeurism' relationship between man and the world" (Sontag, 2013). And, finally, the 'affective turn' stressed the sociological interest to the inner (emotional) life of social actors as determined by and at the same determining social reality: "all societies have their own emotional standards even if such standards are not discussed openly... Emotional standards change over time and vary in social spaces. Changes in emotional standards say a lot about other social changes and can contribute to them" (Zorin, 2016, p. 15). Today socially standardized emotions are defined as empirical indicators of certain concepts and problems. For instance, happiness is considered a priority of the contemporary society as one of the basic emotions that can be historicized, problematized and studied beyond the opposition of constructivism and universalism.

\section{What sociology can and should say about 'mental health'?}

Certainly, it is necessary to identify the disciplinary limits of the sociological interest to such a psychological issue as mental health. This can be done by limiting the focus of the sociological study to the social well-being that can be 'measured' in three perspectives (separately or in a combination). All these perspectives have been empirically tested by the Sociology Chair of the RUDN University together with the Czech and Kazakhstan colleagues in the comparative studies (see, e.g.: Andreenkova, 2011; Davidov et al, 2014; Rudnev, 2013; Schwartz, 1992) of the social well-being of the younger generations of postsocialist countries (see, e.g.: Narbut, Trotsuk, 2018a; 2018b). The first 'dimension' of the social well-being is value orientations that are usually distinguished from values (the level of society instead of value orientations as representing the individual level of values' perception and internalization). The study of value orientations allows to understand the key values of society that determine the set of behavior patterns adopted by the younger generations in the course of socialization. Certainly, individuals not always act according to the declared value orientations, but this does not eliminate the necessity to identify them albeit in the form of standards rather than practical guides to action (see, e.g.: Inglehart, 1997; Inglehart, 2008; Rokeach, 1997).

Our empirical data collected in 2015-2017 on the representative samples of Moscow student youth and compared with the relevant data in other countries proves that the value priorities of today's Russian, Czech and Kazakhstan students have both similarities and differences (in Moscow, 1000 students from different universities were questioned; in Prague and Astana, students of one large university were questioned - 800 students of the Charles University and 500 students of the L.N. Gumilyov Eurasian National University; the samples consisted of bachelor students; two questionnaires were used - on value orientations and on fears and expectations of the student youth; the results of these surveys 
were published mainly in the RUDN Journal of Sociology by N.P. Narbut and I.V. Trotsuk and can be found on the web-site of the journal). For instance, the youth defines success in life as a set of achievements in which wealth/prosperity and creative self-realization are equally important (every second student says so), while career and family (39\%) are in the second place, i.e. the social well-being of the youth depends primarily on personal elements of success that ensure the feeling of freedom - financial and of self-expression. Moreover, the value priorities of the Russian students have not changed over the decade. When asked to rank ten concepts according to the their importance, the students demonstrated a rare unanimity: the main life priorities of the youth are family (62\% versus $71 \%$ a decade ago, but together with its second rank - 80\%) and health (every second student put health in the top three positions); the middle positions on the 'scale of importance' were taken by education, work and friends, wealth and free time are a little behind; the last positions were taken by politics, social activities and religion. The value priorities of the Czech students are same if we consider the final hierarchy although the range of places in the Czech sample is greater; thus, the factors of the younger generations' social well-being seem to be the same in very different societies in the social-economic, political and other terms (see: Narbut, Trotsuk, 2018a; 2018b).

Over the last decade the ideas of the Russian students about what personal qualities allow to achieve success in life have not changed too. First, it is a set of such positive qualities as diligence, communicability, purposefulness, and talent. The second group of qualities with more than $20 \%$ of answers is more heterogeneous and includes ambition and prudence, optimism and honesty, stubbornness and disingenuity, sense of duty, skills to go right through in achieving one's goals and to manipulate others. Over the last decade, this group lost such a personal quality as the ability to compromise, which corresponds to the above mentioned importance of self-realization. And the rarest qualities determining success in life are still negative - deceit, cynicism, greed and lack of principles (but at the same time generosity).

Despite such an ambiguous set of qualities and values the younger generations look to the future with hope and optimism (every second Russian student, 70\% of the Kazakhstan respondents), less often - calmly, without any special hopes and illusions (39\% of the Russian students and every fifth Kazakhstan respondent), or with anxiety and uncertainty. The results of the Czech survey are quite opposite: a third looks to the future with hope and optimism, 37\% - calmly, without any special hopes and illusions, and 27\% - with anxiety and uncertainty. A third of the Russian students consider themselves optimists ( $40 \%$ of the Kazakhstan respondents, but $27 \%$ of the Czech students), a third - realists (39\% and $33 \%$ respectively), and every fourth (28\% of the Czech respondents) responds to the situation.

Thus, in the study of the student value orientations there is no 'psychology' as such, but we can identify the socially determined ideas of the youth about life success and life priorities, which certainly affect their social well-being and self-esteem. Moreover, such an approach can be used in comparative studies due to quite universal questions. Our surveys based on similar questionnaires prove that the value orientations of the student youth of three countries are as strikingly similar in one respect as unexpectedly different in others. For instance, in general, the Czech students are more pessimistic on a number of issues such as their chances for easy and quick employment, but their pessimism can be 
explained by much higher demands for work considering the chances for personal selfrealization and social significance of the job. The Russian youth seem to have a kind of intermediate position between the Czech and Kazakhstan younger generations. On some issues the Russian youth are closer to their Czech peers while on other issues - to their Kazakhstan peers. For instance, in terms of the stability of intergenerational ties and reliance on family and friends, the Kazakhstan students are more 'traditional', while the Czech students more often admit the lack of friends and perceive this situation as normal, but the credibility of their parents in a difficult life situation is just as high. The Czech students declare the highest individualism and personal responsibility, which is explained not only by western individualism and self-sufficiency but also by a higher level of dissatisfaction and mistrust in state institutions and by lower paternalistic expectations. The Kazakhstan students demonstrate a much higher level of conformity and social optimism, which can be explained by the highest level of trust in social institutions based on the pride in both the country's past and the present situation in all spheres of social life.

The second 'dimension' of the social well-being is fears and hopes. Unfortunately, despite the long-term theoretical work and testing of different methodological approa-ched to the study of fears, the very term 'fear' has not lost its excessive ambiguity due to the totality and normality of fears and social risks as sustainable elements of mass consciousness. Moreover, there are many intra- and interdisciplinary definitions of fears that affect their sociological interpretation, for instance, the long psychological tradition of studying anxiety, a significant contribution to which was made by Z. Freud, who distinguished real fears as a reaction to external threats and neurotic fears as repeating a certain experience of the past under or without real threats (Freud, 2006). There is still no universal definition or classification of fears including the social fears that sociology focuses on (see, e.g.: Beck, 2000). Nevertheless, the persistent media presentations of risks as an integral part of contemporary life denies their interpretation just as determinants of various forms of destructive behavior. Therefore, identification of fears allows to assess the social well-being.

As a rule, sociologists seek to describe the general 'repertoire' of fears that prevail in the society as a whole or in its particular social-demographic groups as an important indicator of the social well-being; and also seek to assess the strength and prevalence of certain fears (of death, unemployment, external threats, etc.) (see, e.g.: Gorshkov, 2009; Fears of Russian, 2015). It is important not only to assess the general level of social anxiety or the scale and intensity of a certain fear but also to reconstruct through fears the picture of social reality in the representations of respondents. For instance, high fears of economic disadaptation (declining living standards, unemployment, inability to earn one's or one's family living, etc.) and fears of certain social subjects (aggressive nationalist movements, terrorists, hooligans, etc.) indicate the negative public estimates of the social-economic situation and the distrust in state and social institutions established to protect citizens from economic and criminal threats.

The Russian students' assessments of their emotional state for the last month has not changed over the decade: if we add the shares of the respondents that are constantly experiencing anxiety (16\%) and sometimes feel concerns and fears (33\%), we will get a half of the sample; while $40 \%$ rarely feel anxious. The distribution of answers in the Kazakhstan sample is almost the same except for two indicators: every tenth student constantly feels anxiety (versus every seventh in the Russian sample) due to the larger share 
of respondents not experiencing anxiety (46\%). When feeling strong fear or anxiety, the Russian students usually ask their relatives and friends for advice and support (39\%) or share feelings with friends (42\%), and every fourth prefers to do that in the Internet. The distribution of ways to overcome strong fear/anxiety in the Kazakhstan sample is not very different: every second student (47\%) will ask relatives and friends for help, 38\% will share experiences with friends but only $13 \%$ will do than in social networks, i.e. the Kazakhstan students prefer more 'traditional' patterns of overcoming life difficulties by relying on the closest social circle.

There is an obvious 'normal' ambivalence (it is normal to experience the whole range of emotions and to admit it) in the social well-being of the younger generations of all three countries, which is manifested in the answers to the question "Have you happened in the last few months to..." (with a list of emotions to choose), because positive and negative emotions are equally frequent here. In all three countries every second respondent admits to have been both happy for one's success and to have felt tired and indifferent. These two emotional states prevail in all three samples, but, as in the survey on value orientations, the Czech youth express them more confidently. Thus, not every second Czech respondent but $80 \%$ and $90 \%$ respectively admit that they have experienced such feelings in the last few months. In the Russian and Kazakhstan surveys positive emotions prevail over negative ones, and in Kazakhstan the shares of students experiencing negative emotions are two or three times less that in Moscow (feeling confused or scared, desperate, feeling envy or aggression, etc.). The higher degree of the declared emotionality of the Czech students, probably, can be explained by the fact that in more 'traditional' Russian and Kazakhstan societies (negative) emotions are usually hidden as socially disapproved and stigmatized (especially in terms of gender acceptability).

Sociologists can claim to study psychological fears (phobias) but only through identification of the typical situations in which people experience negative emotions. We used a list of situations that can cause a panic reaction and found that $38 \%$ of the Russian students are afraid of insects, then come some animals and high altitude (27\%), dark rooms (23\%) and public speaking (25\%), etc. The distribution of answers in the Kazakhstan sample is similar in terms of prevailing fears, but there are no obvious leaders: most frequently the students fear dark rooms (25\%) and insects (30\%), high altitude and public speaking (27\%). When in an extremely uncomfortable situation, the Russian students try to stay calm and fight one's fear (34\%), 27\% silently suffer until everything is finished, every fourth responds to the situation, and every tenth gives up. The Kazakhstan students behave differently: $36 \%$ try to stay calm, $38 \%$ respond to the situation, every fourth tries to fight one's fear or waits until everything is finished.

Certainly, social fears are of a greater interest to sociologists, and fears of certain diseases can be considered a kind of transitional to them from the above phobias. The Russian students believe that the most dangerous and terrible 'diseases' (this is a typical media and public definition of some deviant practices too) are HIV/AIDS (63\%), oncology and drug addiction (every second), then comes alcoholism, venereal and cardiovascular diseases (every third), impossibility to have children (27\%), tobacco addiction (every fourth) and mass epidemics (every fifth). HIV/AIDS is also a leader for the Kazakhstan respondents (71\%), then come drug addiction (44\%) and oncology (39\%), tobacco addiction, alcoholism, cardiovascular diseases and reproductive problems (from $23 \%$ to $27 \%$ ), and the 
last ones are venereal diseases (18\%) and pandemics (15\%). In other words, the dominant threats are diseases and addictions that worsen the quality of life as such and also due to their social stigmatization, which is obviously determined by the media presentations of such diseases and addictions as being widespread and personal responsibility.

To identify key social fears of students, we used the question "When thinking about your future, what do you fear the most?". The distribution of fears of the Russian students has not changed significantly over the decade: the leader is still the fear of losing the loved ones, then come economic fears (poverty, unemployment and low salary) and fear of incurable diseases. The third group of the Russian students' fears consist of fears of childlessness, loneliness, and of disappointment in profession, love or studies. In the fourth group, there are fears of not getting married and of death, fears of public humiliation, becoming a victim of crime, unplanned pregnancy, serious illness, and of not having the Internet/ computer. Certainly, these data are difficult to interpret not to mention strong generalizations; however, one can easily note that over the decade the general level of the youth's anxiety has increased and the ratio of prevailing fears has changed. Thus, the level of some personal fears has declined (for example, of loneliness), but the level of other fears, on the contrary, has increased (fears of being disappointed in profession or love); economic fears have intensified together with the awareness of the risks to personal security (to get under investigation, to die, to become a victim of criminals), and the shares of those who fear mass epidemics and losing access to the Internet/computer have increased four times.

These data confirm the high 'normal' (for the contemporary risk society) anxiety of the younger generations, because today we are surrounded by an incredible number of threats beyond individual control (terrorism, technological, environmental and natural disasters, military threats, etc.), which are not 'real' as such (and as presented in the media) but rather potentially dangerous and affecting our social well-being. This is proved by the fact that the identified high anxiety does not determine low estimates of one's life. Thus, although among the Kazakhstan respondents the share of students satisfied with their life is larger (83\% versus 64\% in Moscow and 77\% in Prague), this indicator is high in all three samples. This, probably, means that most fears of family-personal and financial-economic nature are not still relevant for the youth and the risks of social-political and catastrophic nature are considered inevitable due to the media discourse that 'normalizes' them.

Finally, the third and most 'psychological dimension' of social well-being is 'measurement' of happiness, because many sociological projects reduce the definition of happiness to subjective well-being, i.e. to its cognitive estimates (life satisfaction) and affective pleasures from life. Certainly, this is inevitable if we want to compare societies by their level of happiness: we have to use quite simplistic and binary measures that do not say much about real personal feelings and determine unpredictable and unexplainable changes in countries' ranking positions in the annual World Rankings of Happiness (for instance, in 2015-2017, Russia was on position 59 and Serbia - on 78, while in 2014-2016, Russia was on position 49 and Serbia - on 73). However, such measures allow to explain some global trends, for example, in migration: "there are large gaps in happiness between countries, and these will continue to create major pressures to migrate... In general, those who move to happier countries than their own will gain in happiness, while those who move to unhappier countries will tend to lose... One obvious solution, which has no upper limit, is to raise the happiness of people in the sending countries... by helping them to grow their 
own levels of trust, and institutions of the sort that make possible better lives in the happier countries" (World Happiness Report, 2018, p. 9).

The fact that many sociological projects reduce the definition of happiness to subjective well-being is determined not so much by numerous interpretations of happiness (see, e.g.: Kachur, 2013) as by the gradual transformations in the direction of refusal to interpret happiness as social 'involvement' or 'fate' (luck) in favor of personal life satisfaction, i.e. of admitting the relationship of happiness with the level of personal freedoms and with the quality of life. "Today happiness is defined primarily as the greatest inner satisfaction with the conditions of one's existence, as fullness of life and awareness of one's purpose" (Mishutina, 2008, p. 12). Nevertheless, such fullness and awareness depend on family status, friendships and social relations (they ensure psychological support), availability of work and/or a source of income and its level, health status, free time, level of education, etc. (see, e.g.: Veenhoven, 1991).

For instance, a survey on the sample of the RUDN University students in 2018 showed that the majority (90\%) consider themselves happy and claim that on the 10-point scale of happiness (1 means the lack of happiness and 10 - absolute happiness) they are either quite happy (every second respondent considers himself happy for 7-8 points) or very happy (every fourth respondent considers himself happy for 9-10 points). Such a high level of happiness (and, respectively, social well-being) can be explained partly by the lack of life experience and youthful positive attitude, but no less important are the main determinants of happiness named by the students - family (80\%), friends (73\%), health $(72 \%)$, having a loved one (67\%), then free time and hobbies, fulfillment of desires and dreams (58\%), financial situation and profession/work (52\%), and luck (49\%), which are fully consistent with the respondents' ideas about most important things in life - good family (77\%), good health (66\%), favorite work/profession (53\%), having a loved one $(48 \%)$, well-being of loved ones (46\%), wealth (44\%), inner harmony (38\%), favorite hobby (32\%) and children (30\%) followed by optimism $(27 \%)$, world peace $(21 \%)$ and faith in God (19\%). In other words, these are 'things' that the students either have or are too young to have, which is socially acceptable; therefore, the youth do not have enough grounds to consider themselves unhappy in general.

\section{Conclusion}

Certainly, the article presents a very short and sketchy overview of the sociological possibilities to study empirically such a psychological issue as mental health by focusing only on the social well-being 'measured' in three perspectives. However, even such an overview proves that quite simple and traditional sociological questionnaires provide enough data about the social well-being if we consider different 'dimensions' of it - (1) value orientations, (2) fears and hopes, and especially (3) happiness that is often defined as subjective well-being. As was mentioned above, when we consider the social well-being through fears, we should take into account life satisfaction not to make wrong conclusions based only the high level of anxiety. The same applies to happiness: even in a difficult life situation a person can be happy provided the high life satisfaction. For instance, if people consider themselves free to choose and control their lives, they are happier than people without such freedoms but with much higher living standards (Freedom in the 
world, 2010). According to our survey on happiness, the student youth interprets happiness mainly as a subjective concept (which also explains the high level of happiness) determined mainly by personal 'things' (family, health, etc.) rather than by 'external' factors. Therefore, such a 'psychological dimension' of the social well-being can be considered a reasonable and justified sociological approach to the study of the national 'mental health' and factors determining it. 
Ирина В. Троцук ${ }^{1}$

РУДН Универзитет

Департман за хуманистичке и друштвене науке

Катедра за социологију

Москва (Руска Федерација)

\title{
ТРИ ПРИСТУПА СОЦИОЛОШКОМ ИСТРАЖИВАњУ ДРУШТВЕНОГ БЛАГОСТАҢА 2
}

\author{
(Превоg In Extenso)
}

Сажетак: Свет који се глобализује и диверзификује захтева од социологије да стално редефинише своје границе, посебно у односу на психологију. Такође је неопходно да се идентификује особеност социолошког интереса за такво психолошко питање као што је ментално здравље. Ово може да се постигне усредсређујући фокус социолошког истраживања на друштвено благостање које може да се „мери” из три перспективе: прво, идентификација вредносних оријентација; друго, описивање страховања која преовлађују у друштву или у његовим посебним групама, и треће, покушаји да се мери ниво среће, његови фактори и саставни елементи у изразима њихове „величине”, промена и не/мењања на националном нивоу и у упоредној перспективи. Чланак представља неке емпиријске примере све три социолошке „димензије” друштвеног благостања.

Кључне речи: друштвено благостање; вредносне оријентације; страховања; срећа; анкета.

\section{Увод}

Социологија је врло млада дисциплина, што је условило њену интердисциплинарност захваљујући чињеници да „друштвени поредак” као кључан и суштински појам социологије има далеко дужу историју него сама социологија па је први пут разматран у тзв. „Хобсовом питању” (Filippov, 2017), а такође истовремено постоји напети однос између социологије и других друштвених наука које претендују да проучавају потпуно исте феномене и аспекте друштвене стварности као што су „друштвени развој”, „сукоби”, „правда/неправда” и многи други. Посебно, ови изрази се односе на политичка питања, што објашњава „политизацију” соцологије и трајних спорења учењака о томе да ли је исправно да се говори о

1 irina.trotsuk@yandex.ru

2 Истраживање је подржала Руска фондација за основна истраживања. Пројекат бр. 18-01100993 „Срећа као интердисциплинарни конструкт: Варијације социолошке концептуализације и операционализације”. 
политичкој социологији као грани социологије или треба оставити сва политичка питања само политичкој науци. Овакви спорови тешко да ће да буду разрешени за појмове „друштвеног поретка”, „напретка”, „правде”, итд. који чине вечна питања социологије (и друштвених наука) чак и у условима њихове актуалне оштре критике (видети нпр.: Flyvbjerg, 2001). Овакви спорови такође обликују вечне (мада доста имагинарне) конфронтације између „прогресивне” и „конзервативне” традиције, као и друштвено-конструктивистичких и универзалистичких теорија, те између заговорника правне или нормалне/нормативистичке замисли друштвеног поретка (видети нпр.: Abrutyn, Carter, 2014) и њихових критичара који доказују да ми данас живимо под „анормативним” бирократским прописима који брже одговарају на нове друштвене промене, али занемарују традиционално интересовање о легитимности (видети нпр.: Archer, 2018; Turner, 2010).

На овај начин, социологија и политичка наука имају многа заједничка интересовања и постоји очигледан тренд политизације социологије стога што владе и елите теже да контролишу социолошки рад услед трајних глобалних подела Запада и Истока, Севера и Југа, класа и раса, и настајања нових раздвајања као што је дигитални јаз, која чине друштвени поредак нестабилним и непредвидивим. Свакако, социолози би „требало да имају неку представу о томе какво би добро друштво требало да буде и који су политички циљеви да би се оно остварило. Спроводећи истраживање, међутим, истраживач би требало да има неопходну дистанцу у односу на друштвене проблеме... Сви имамо властите вредносне премисе, преференције, предрасуде... Спроводећи озбиљан социолошки рад, истраживач мора имати на уму да нам је потребно извесно критичко дистанцирање. Без тога, неко би могао да покуша да манипулише подацима у циљу тежње за политичким објективним циљевима, игноришући супротне доказе” (Martinelli, 2018, p. 24).

Ово дистанцирање је очигледан захтев уколико узмемо у обзир однос социологије и политичке науке, али исто важи и за однос између социологије и (социјалне) психолгије, које је ретко узимано у обзир а да се и не помиње проблематизација овог дистанирања. На овај начин, горњи исказ се може лако преформулисати за анализу на микро нивоу, т.j. у социјално-психолошкој перспективи. Социолог би требало да има представу о томе шта би то требало да буде добра личност; међутим, спроводећи истраживање, истраживач би требало да има неопходну емоционалну непристрасност у односу на друштвене проблеме које он или она анализирају као и у односу на стварне људе са којима он или она комуницирају. Сви имамо личне вредносне премисе, преференције, предрасуде и емоције; међутим, предузимајући озбиљан социолоки рад, истраживач мора да држи на уму да нам је потребна извесна критичка и емоционална дистанца. У супротном, неко би могао да покуша да манипулише подацима да би следио личне циљеве, да игнорише супротне доказе и да указује предност доказима који подржавају властите односе са анкетиранима и који одговарају властитом погледу на свет.

Данас ми живимо у свету са растућим размерама и оштрином проблема менталног здравља, посебно у постконфликтним и транзиционим друштвима, са глобалним порастом броја корисника алкохола и других психоактивних супстанци, самоубистава, депресије и анксиозно-депресивних поремећаја, итд. То доводи до тога да социолози буду консултовани о државним стратегијама за превенцију 
коришћења дрога и алкохола, за јачање друштвено-културних фактора менталног здравља, за развој друштвеног окружења толерантног/пријатељског према људима са менталним поремећајима итд. (на пример, можемо да прегледамо званичне интернет странице руске владе, неких руских министарстава и других државних и регионаних власти и да пронађемо да многи органи власти поседују посебна аналитичка одељења која спроводе или наручују социолошке анкете да би установили какво је јавно мњење о планираним одлукама и променама). Ово, такође, доприноси томе да социолози верују да они имају право да доносе стручне судове и о питањима за која је претходно сматрано да представљају домен (социјалне) психологије. Међутим, такво веровање може да вара и да доведе до озбиљних грешака пошто социолози никада нису проучавали и никада неће проучавати ментално здравље, а конфузије су овде одређене изузетном популарношћу израза „менталитет” с веома збуњујућом и двосмисленом дефиницијом, као и растућим социолошким интересовањем за питања самоидентификације како у сазнајном тако и у афективном погледу.

Други темељ „психологизације” социологије је правна последица и екстензија бројних „обрта” у друштвеним наукама и хуманистичким дисциплинама у 20. веку. „Лингивистички преокрет” је сугерисао тумачење друштвених чињеница као представљања дискурзивних механизама и људског живота као једног „аутолингвистичког феномена” (Löfgren, 1981). „Наративни преокрет” је истицао „наративну природу” свих текстова укључујући личне и групне биографије (видети нпр. Franzosi, 1998; Fraser, 2004) у оквиру дискурса који конструишу друштвену реалност. „Визуелни преокрет” наглашава значај визуелне „димензије” личног и друштвеног живота услед свеприсутности визуелних слика и „успостављања односа 'хроничног воајеризма' између човека и света” (Sontag, 2013). Такође, на крају, „афективни обрт” који је наглашавао социолошко интересовање за унутрашњи (емоционални) живот друштвених делатника како је он одређен од стране друштвене стварности и истовремено сам одређује друштвену стварност: „сва друштва поседују своје властите емоионалне стандарде чак и ако ови стандарди нису отворено продискутовани... Емоционални стандарди се мењају кроз време и разликују се у друштвеним просторима. Промене у емоционалним стандардима пуно говоре о другим друштвеним променама и могу да им допринесу" (Zorin, 2016, p. 15). Данас се друштвено стандардизоване емоције дефинишу као искуствени показатељи одређених појмова и проблема. На пример, срећа се сматра за приоритет у савременом друштву као једна од основних емоција која може да буде хисторизована, проблематизована и проучавана изван супротстављености конструктивизма и универзализма.

\section{Шта социологија може и требало би да каже о „менталном здрављу”}

У сваком случају, неопходно је да се идентификују дисиплинарне границе социолошког интересовања за такво психолошко питање какво је ментално здравље. Ово може да се учини путем ограничавања фокуса социолошког истраживања на друштвено благостање које може да се „мери” из три перспективе (одвојено 


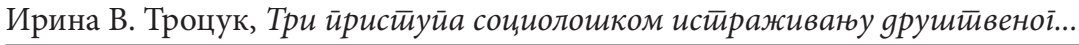

и у комбинацији). Све ове перспективе су емпиријски тестиране од стране председавајућег Одељења за социологију РУДН универзитета заједно са чешким и казахстанским колегама у упоредним студијама (видети нпр.: Andreenkova, 2011; Davidov et al, 2014; Rudnev, 2013; Schwartz, 1992) друштвеног благостања млађе генерације у постсоцијалистичким земљама (видети нпр.: Narbut, Trotsuk, 2018a; 2018b). Прва „димензија” друштвеног благостања су вредносне оријентације које се обично разликују од вредности (ниво друштва уместо вредносних оријентација које представљају индивидуални ниво опажања и поунутрашњења). Проучавање вредносних оријентација омогућава да се разумеју кључне вредности друштва које одређују скуп образаца понашања усвојених од стране млађих генерација током процеса социјализације. Свакако, поједини не делују увек у складу са прокламованим вредносним оријентацијама, али ово не елиминише неопходност да оне буду идентификоване макар у облику стандарда пре него практичних водича за деловање (видети нпр. Inglehart, 1997; Inglehart, 2008; Rokeach, 1997).

Наши емпиријски подаци прикупљени од 2015. до 2017. године на репрезентативном узорку студентске омладине Москве и упоређени са релевантним подацима у другим земљама доказују да вредносни приоритети данашњих руских, чешких и казахстанских судената поседују како сличности тако и разлике (у Москви је испитано 1000 студената са разних универзитета; у Прагу и Астани, испитани су студенти једног великог универзитета - 800 студената Карловог универзитета и 500 студената Евроазијског националног универзитета „Л. Н. Гумиљов”; узорци су се састојали од дипломираних студената; коришћена су два упитника - о вредносним оријентацијама и о страховањима и очекивањима студентске омладине; резултате ових анкета су углавном објавили Н. П. Нарбут и И. В. Тротсук у РУДН Журнал за социологију, и могу да се нађу на вебстрани овог часописа. На пример, омладина дефинише успех у животу као скупину постигнућа у којима су богатство/просперитет и креативно самоостварење подједнако важни (сваки други студент се тако определио), док су каријера и породица (39\%) на другом месту, то јест, друштвено благостање омладине зависи првенствено на личним елементима успеха да се обезбеди осећање слободе - финансијске и самоизражавања. Поред тога, вредносни приоритети руских студената се нису мењали током деценије. Када је затражено од њих да рангирају десет појмова према њиховом значају, студенти су показали ретку једногласност: главни животни приоритети омладине су породица (62\% према $71 \%$ пре једне деценије, али заједно с њеним другим рангом - 80\%) и здравље (сваки други студент је поставио здравље на прве три позиције); на средњим положајима на „скали значајности” су заузели образовање, рад и пријатељи, богатство и слободно време су мало заостали; последње положаје су заузеле политика, друштвене активности и религија. Вредносни приоритети чешких студената су идентични уколико узмемо у обзир коначну хијерархију, мада је распон места (ранга) у чешком узорку већи; на овај начин, фактори друштвеног благостања млађе генерације изгледа да су исти у врло различитим друштвима с обзиром на њихове друштвено-економске, политичке и друге изразе (Narbut, Trotsuk, 2018a; 2018b).

Током прошле деценије, идеје руских студената о томе који лични квалитети дозвољавају постизање успеха у животу такође се нису мењали. Прво, ради се о скупу таквих позитивних квалитета као што су марљивост, комуникативност, 
циљна усмереност и таленат. Друга група квалитета које су испитаници бирали у више од 20\% одговора је хетерогенија и укључује амбицију и економичност, оптимизам и поштење, упорност и ингениозност, осећање дужности, вештине да се иде директно ка постизању властитих циљева и да се манипулишу други. Током протекле деценије, ова група је изгубила такве личне квалитете као што је способност за постизање компромиса, што кореспондира с горе поменутим значајем самореализације. А најређи квалитети који детерминишу успех у животу су и даље негативни - превара, цинизам, лакомост и одсуство принципа (али истовремено и дарежљивост).

Упркос тако амбивалентном скупу квалитета и вредности, млађа генерација гледа на будућност са надом и оптимизмом (сваки други руски студент, 70\% казахстанских испитаника), ређе на будућност гледају мирно, без било каквих посебних надања и илузија (39\% руских студената сваки пети казахстански испитаник), или са осећањем зебње и несигурности. Резултати анкете у Чешкој су потпуно супротни; трећина гледа на будућност с надом и оптимизмом, 37\% - мирно, без било каквих посебних надања и илузија, и $27 \%$ - са осећањем анксиозности и неизвесности. Трећина руских студената себе сматра оптимистичним (40\% казахтанских испитаника, али само 27\% чешких студената), трећина - себе сматра реалистичнима (39\% и $33 \%$ респективно), и сваки четврти (28\% чешких испитаника) реагује на дату ситуацију.

Дакле, у истраживању вредносних оријентација студената нема „психологије” као такве, али ми смо у стању да идентификујемо друштвено детерминисане идеје младих о успеху у животу и о животним приоритетима, које сигурно утичу на њихово друштвено благостање и самопоштовање. Поред тога, такав приступ може да се употреби у упоредним истраживањима захваљујући потпуно универзалним питањима. Наше анкете базиране на сличним упитницима доказују да су вредносне оријентације студентске омладине у три земље исто толико фрапантно сличне у једном погледу колико се неочекивано разликују у другим аспектима. На пример, генерално гледајући, чешки студенти су више песимистични у погледу извесног броја питања као што су то њихове шансе за лако и брзо запослење, али њихов песимизам може да се објасни далеко вишом потражњом за запослењем које узима у обзир шансе за лично самоостварење и друштвену значајност запослења. Руска омладина изгледа да заузима неку врсту средње позиције између чешке и казахстанске млађе генерације. По неким питањима руска омладина је ближа својим чешким колегама, док су по другим питањима - ближи својим казахстанским колегама. На пример, у погледу стабилности унутаргенерацијских веза и ослањања на породицу и пријатеље, казахстански студенти су више „традиционални”, док чешки студенти чешће признају недостатак пријатеља и сагледавају ову ситуацију као нормалну, али кредибилност њихових родитеља у тешким животним ситуацијама је подједнако висока. Чешки студенти исказују највиши степен индивидуализма и личне одговорности, што се не објашњава само западњачким индивидуализмом и самодовољношћу него и вишим нивоом незадовољства и неповерења у државне институције и нижим патерналистичким очекивањима. Казахстански студенти показују далеко виши ниво конформизма и друштвеног оптимизма, што може да се објасни њиховим највишим нивоом поверења у друштвене институције утемељене 


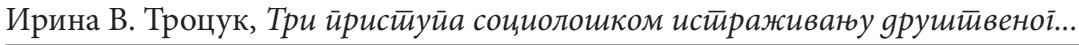

на поносу како у прошлости своје земље тако и у њеној садашњој ситуацији у свим сферама друштвеног живота.

Друга „димензија” друштвеног благостања су страховања и надања. Нажалост, упркос дугорочном теоријском раду и тестирању различитих методолошких приступа истраживању страхова, сам израз „страх” до данас није изгубио своју претерану двосмисленост услед тоталности и нормалности страхова и друштвених ризика као подлежећих елемената масовне свести. Поред тога, постоје многе интраи интер-дисциплинарне дефиниције страхова које утичу на њихово социолошко тумачење, на пример, дуга психолошка традиција истраживања анксиозности, којој је значајно допринео S. Freud, који је разликовао стварне страхове као реакцију на спољашње претње, с једне стране, те неуротичне страхове који понављају одређена искуства из прошлости под утицајем или без утицаја стварних претњи (Freud, 2006). И даље не постоји универзална дефиниција или класификација страхова, укључујући друштвене страхове на које се усредсређује социологија (упореди нпр. Beck, 2000). Па ипак, стално медијско представљање ризика као саставног дела савременог живота, оспорава тумачење страхова само као детерминанти различитих облика деструктивног понашања. Стога, идентификација страхова омогућава да се процени друштвено благостање.

Као правило, социолози теже да опишу општи „репертоар” страхова који преовладавају у друштву као целини или у његовим посебним социо-демографским групама као важан показатељ друштвеног благостања; они такође теже да процене јачину и преовладавање одређених страхова (од смрти, незапослености, од спољашњих опасности, итд.) (уп. нпр. Gorshkov, 2009; Fears of Russian, 2015). Важно је не само да се промени општи ниво друштвене анксиозности или размере и интензитет одређеног страха, него и да се кроз те страхове реконструише слика друштвене стварности у представама испитаника. На пример, високи степен страха од економске неприлагођености (опадајућег животног стандарда, незапослености, неспособности да се заради за властити живот и живот властите породице, итд.) и страхови од одређених друштвених субјеката (агресивних националистичких покрета, терориста, хулигана, итд.) указују на негативну процену јавности о друштвено-економској ситуацији и на неповерење у државу и друштвене институције које су установљене да заштите грађане од економских и криминалних претњи.

Процене руских студената о њиховом емоционалном стању за последњих месец дана, нису се мењале током истраживане деценије: уколико саберемо удео испитаника који перманентно доживљавају анксиозност (16\%) и који понекад осећају бригу и страхове (33\%), добићемо половину узорка; истовремено $40 \%$ ретко се осећају анксиознима. Дистрибуција одговора у казахстанском узорку је готово идентична, осим за два показатеља: сваки десети студент константно осећа анксиозност (према сваком седмом испитанику у руском узорку), услед већег удела испитаника који не доживљавају анксиозност (46\%). Када осећају снажан страх или анксиозност, руски студенти обично питају своје рођаке и пријатеље за савет и помоћ (39\%) или деле своја осећања са пријатељима (42\%), а сваки четврти преферира да потражи помоћ на интернету. Дистрибуција начина за превазилажење снажног страха/анксиозности у казахстанском узорку се не разликује пуно: сва- 
ки други студент (47\%) потражиће помоћ од рођака и пријатеља, 38\% ће поделити своја искуства са пријатељима, али само 13\% ће потражити помоћ на друштвеним интернет мрежама, т.j. казахстански студенти преферирају више „традиционалне” обрасце превазилажења животних тешкоћа путем ослањања на најужи друштвени круг (рођака и пријатеља). Постоји очигледна „нормална” амбивалентност (нормално је да се доживљава читав спектар емоција и да се то призна у контексту друштвене добробити млађе генерације све три земље; ово се манифестује у одговорима на питање „Да ли вас је у последњих неколико месеци задесила ...” (следи листа емоција између којих испитаници бирају), зато што су позитивне и негативне емоције овде подједнако учестале. У све три земље сваки други испитаник признаје да је био и срећан због властитог успеха, као и да се осећао уморним и индиферентним. Ова два емоционална стања преовлађују у сва три узорка, али, као и у анкети о вредносним оријентацијама, чешка омладина их изражава с више самопоуздања. Тако, не само сваки други чешки испитаник, него њих $80 \%$ и $90 \%$ у руском и казахстанском узорку респективно признаје да су искусили таква осећања у последњих неколико месеци. У руској и казахстанској анкети позитивне емоције преовлађују над негативнима, а у Казахстану удели студената који доживљавају негативне емоције су два или три пута мање учестали него у Москви (осећање збуњености или страха, очајања, осећање зависти или агресивности, итд.). Виши степен исказане емоционалности чешких студената, вероватно може да се објасни чињеницом да у „традиционалнијем” руском и казахстанском друштву, (негативне) емоције су обично скривене пошто су друштвено неодобраване и стигматизоване (нарочито у погледу родне прихватљивости).

Социолози могу да тврде да истражују психолошка страховања (фобије) али само кроз идентификацију типичних ситуација у којима људи доживљавају негативне емоције. Ми смо користили листу ситуација које могу да проузрокују паничне реакције и установили смо да се $38 \%$ руских студената боји инсеката, за њима долазе неке животиње и велика висина (27\%), тамне собе (23\%) и јавно говорење (25\%), итд. Дистрибуција одговора у казахстанском узорку је слична у погледу преовлађујућих страховања, али овде нема очигледних прворангираних страховања: најчешће се студенти боје тамних соба (25\%) и инсеката (30\%), великих висина и говорења у јавности (27\%). Када су у некој изразито неугодној ситуацији, руски студенти настоје да остану мирни и да се боре против властитих страхова (34\%), 27\% тихо пате док се све не заврши, сваки четврти реагује на ситуацију, и сваки десети се предаје. Казахстански студенти се понашају друкчије: $36 \%$ покушава да остане мирно, $38 \%$ одговарају на ситуацију, сваки четврти покушава да се бори против властитих страхова или чека док се све не заврши.

Свакако, друштвени страхови су занимљивији за социологе, а страхови од одређених болести могу да се посматрају као нека врста прелаза од друштвених страхова ка горе поменутим фобијама. Руски студенти верују да су најопасније и страшне „болести” (ово је такође типична медијска и званична дефиниција неких девијантних пракси) HIV/AIDS (63\%), онкологија и злоупотреба дрога (сваки други испитаник), потом долази алкохолизам, венеричне и кардиоваскуларне болести (сваки трећи испитаник), стерилитет (27\%), зависност од дувана (сваки четврти) и масовне епидемије (сваки пети). HIV/AIDS је такође на првом месту за казахстан- 
ске испитанике (71\%), следи зависност од дрога (44\%) и онкологија (39\%), зависност од дувана, алкохолизам, кардиоваскуларне болести и репродуктивни проблеми (од $23 \%$ до 27\%), а на последњем месту су венеричке болести (18\%) и пандемије (15\%). Другим речима, доминантне претње су болести и зависности које погоршавају квалитет живота као таквог и такође за собом повлаче друштвену стигматизацију, која је очигледно детерминисана медијском презентацијом таквих болести и зависности као широко распрострањених и као болести и зависности које представљају личну одговорност.

Да бисмо идентификовали кључне друштвене страхове студената, користили смо питање: „Када размишљате о вашој будућности, чега се највише плашите?” Дистрибуција страхова руских студената се није значајно променила током истраживане деценије: на првом месту је и даље страх од губитка вољених особа, следе економски страхови (сиромаштво, незапосленост и ниска примања) као и страх од неизлечивих болести. Трећа по реду група страховања руских студената садржи страхове од немања порода, усамљености и разочарања у професији, љубави или студијама. У четврту групу спадају страхови да се неће ступити у брак и страх од смрти, страхови од јавног понижења, да се не постане жртва криминала, непланиране трудноће, озбиљне болести, као и страх од немања интернета/компјутера. Свакако, ови подаци су тешки за тумачење, а да се и не помињу јака уопштавања; међутим, можемо лако да опазимо да је током истраживане деценије општи ниво анксиозности омладине порастао, а ранг преовлађујућих страхова се променио. Тако се ниво неких личних страхова смањио (на пример, страх од усамљености), али ниво других страхова, напротив, повећао се (страхови од разочарања у занимању и љубави); економски страхови су добили на интензитету истовремено са свешћу о ризицима за личну безбедност (да се доспе под истрагу, да се умре, да се постане жртва криминалаца), а удео оних који се боје масовних епидемија и губитка приступа интернету/компјутеру се повећао четвороструко.

Ови подаци потврђују високи „нормални” степен анксиозности (за савремено друштво ризика) млађих генерација, пошто смо данас окружени невероватним бројем претњи које су изван контроле појединца (тероризам, технолошке, еколошке и природне катаклизме, војне претње итд), које нису „реалне” као такве (као што су представљене у медијима) већ су потенцијално опасне и утичу на наше друштвено благостање. Ово је доказано чињеницом да уочени високи степен анксиозности не одређује ниске процене властитог живота испитаника. Тако, мада је међу испитаницима из Казахстана удео студената задовољних својим животом већи (83\% према 64\% у Москви и 77\% у Прагу), овај показатељ је висок у сва три узорка. Ово, вероватно, значи да већина страхва породично-личне и финансијско-економске природе још нису релевантни за омладину а ризици друштвено-политичке и катастрофичне природе се сматрају неизбежним услед дискурса медија који их „нормализују”.

Коначно, трећа и у највећем степену „психолошка димензија” друштвеног благостања јесте „мерење” среће, с обзиром да многи социолошки пројекти своде одређење среће на субјективно осећање добробити, т.j. на његову когнитивну процену (задовољство животом) и афективна задовољства од живота. Свакако, ово је неизбежно уколико желимо да упоређујемо друштва према њиховом нивоу среће; приморани смо да користимо врло поједностављене и бинарне мере које не 
говоре пуно о стварним личним осећањима и које детерминишу непредвидљиве и необјашњиве промене у позицијама ранга појединих земаља у годишњим извештајима Светског рангирања среће (на пример, у периоду 2015 - 2017, Русија је била на позицији 59 а Србија - на позицији 78, док је у периоду 2014 - 2016, Русија била на 49. месту а Србија - на 73). Овакве мере, међутим, дозвољавају да се објасне неки глобални трендови, на пример, у миграцијама: „постоје велики јазови у срећи између земаља, а они ће наставити да стварају снажне притиске на мигрирање ... Уопштено говорећи, они који се преместе у срећније земље него што је то њихова властита земља, стећи ће добит у срећи, док они који се преместе у мање срећне земље, имаће тенденцију да губе... Једно очигледно решење, које нема горњу границу, јесте да се подигне ниво среће људи у земљама емиграције... помажући им да подигну властите нивое поверења, и изграде такве институције које чине могућим бољи квалитет живота какав постоји у срећнијим земљама" (Светки извештај о срећи, 2018: 9).

Чињеница да многи социолошки пројекти своде дефиницију среће на субјективну добробит је условљена не толико бројним тумачењима среће (уп. нпр.: Kachur, 2013) колико постепеним преображајем у смеру одбијања да се протумачи срећа као друштвено „уплитање” или „судбина” (добра или зла срећа) у корист личног задовољства животом, нпр. признавањем међузависности среће и нивоа личних слобода те квалитета живота. „Данас се срећа дефинише првенствено као највећи степен унутрашњег задовољства условима појединчеве егзистеније, као испуњеност живота и свест о личним циљевима” (Mishutina, 2008: 12). Таква испуњеност и свест, међутим, зависе од статуса породице, пријатељстава и друштвених односа (они обезбеђују психолошку подршку), од расположивости запослења и/или извора прихода и њиховог нивоа, стања здравља, слободног времена, нивоа образовања итд (уп. нпр. Veenhoven, 1991).

Анкета на узорку студената РУДН универзитета у 2018. години, на пример, показала је да већина (90\%) себе сматрају срећнима и тврде да су на десеточланој скали среће (1 значи недостатак среће а 10 - апсолутну срећу), они били сасвим срећни (сваки други испитаник себе сматра срећним од 7 до 8 поена) или да су веома срећни (сваки четврти испитаник се сматра срећним од 9 до 10 поена на скали среће). Тако висок ниво среће (а, стога и друштвеног благостања) може делимично да се објасни недостатком искуства и младалачким позитивним ставом, али не мање значајне су главне детерминанте среће које су навели сами студенти - породица (80\%), пријатељи (73\%), здравље (72\%), имати вољену/вољеног (67\%), него што су то слободно време и хобији, остваривање жеља и снова (58\%), финансијска ситуација и занимање/рад (52\%), и добра срећа (49\%), што је у потпуној конзистенији са идејама испитаника о најважнијим стварима у животу - добра породица (77\%), добро здравље (66\%), омиљен посао/занимање (53\%), имати вољену/вољеног (48\%), добробит вољених особа (46\%), богатство (44\%), унутрашња хармонија (38\%), омиљени хоби (32\%) и деца (30\%), за којима следе оптимизам (27\%), светски мир (21\%) и вера у Бога (19\%). Другим речима, ово су „ствари” које студенти или већ имају или су одвише млади да поседују оно што је друштвено прихватљиво; стога, млади немају довољно темељних искустава да себе сматрају несрећнима у начелу. 


\section{Закључак}

Свакако, овај чланак представља врло сажет и само скицирани преглед социолошких могућности емпиријског истраживања таквих психолошких проблема као што су ментално здравље путем усредсређивања само на друштвено благостање „мерено” из три перспективе. Чак и такав преглед, међутим, доказује да врло једноставни и традиционални социолошки упитници обезбеђују довољно података о друштвеној добробити уколико узмемо у обзир њене различите „димензије” - (1) вредносне оријентације, (2) страхове и наде, и нарочито (3) срећу која се често дефинише као субјективна добробит. Као што је горе напоменуто, када разматрамо друштвену добробит кроз страхове, требало би да узмемо у обзир задовољство животом да не бисмо правили погрешне закључке засноване само на високом нивоу анксиозности. Исто се односи на срећу: чак и у тешким животним ситуацијама особа може да буде срећна уколико постоји висок степен задовољства животом. На пример, уколико људи себе сматрају слободнима да бирају и контролишу своје животе, они су срећнији него људи који не поседују такве слободе али имају знатно виши животни стандард (Freedom in the world, 2010). Према нашој анкети о срећи, студентска омладина тумачи срећу пре свега као субјективни појам (што такође објашњава висок ниво среће) одређен пре свега личним „стварима” (породица, здравље, итд.) пре него „спољашњим” чиниоцима. Стога, таква „психолошка димензија” друштвеног благостања може да се сматра разумним и оправданим социолошким приступом истраживању националног "менталног здравља" и чиниоца који га одређују.

\section{REFERENCES / ЛИTЕРАТУРA}

Abrutyn, S., Carter, M.J. (2014). The decline in shared collective conscience as found in the shifting norms and values of etiquette manuals. Journal for Theory of Social Behaviour, vol 43 (2).

Andreenkova, A.V. (2011). Cross-country comparative analysis in social sciences: Methodology, development, and the current state. Mir Rossii, no 3 [in Russian].

Archer, M.S. (2018). The iron bars get closer: Anormative social regulation. Monitoring of Public Opinion: Economic and Social Changes, no 5.

Beck, U. (2000). Risk Society: Towards a New Modernity. Moscow [in Russina].

Davidov, E., Meuleman, B., Cieciuch, J., Schmidt, P., Billiet, J. (2014). Measurement equivalence in cross-national research. Annual Review of Sociology, vol 40.

Fears of Russians (2015). Available at:https://www.levada.ru/2015/08/18/strahi-rossiyan-3 [in Russian].

Filippov, A.F. (2017). Other "people of Hobbes": On the philosophical sources and perspectives of one sociological mistake. A.N. Dmitriev, N.V. Samutina, E.A. Vishlenkova (Eds.). Garden of Scientific Delights. Moscow [in Russian].

Flyvbjerg, B. (2001). Making Social Science Matter: Why It Can't Succeed Again. CambridgeNew York.

Franzosi, R. (1998). Narrative analysis - or why (and how) sociologists should be interested in narrative. Annual Review of Sociology, vol 24. 
Fraser, H. (2004). Doing narrative research: Analyzing personal stories line by line. Qualitative Social Work, vol 3.

Freedom in the world (2010). Available at: https://freedomhouse.org/report/freedomworld/freedom-world-2010.

Freud, S. (2006). Hysteria and Fear. Moscow [in Russian].

Gorshkov, M.K. (2009). Phobias, threats, and fears: The social-psychological state of the Russian society. Sociological Studies, no 7 [in Russian].

Inglehart, R. (1997). Postmodern: Changing values and changing societies. Political Studies, no 4 [in Russian].

Inglehart, R. (2008). Changing values among western publics from 1970 to 2006. West European Politics, vol 31.

Kachur, N.V. (2013). Evolution of the sociological interpretation of happiness. News of Saratov University. Series: Sociology. Political Science, vol 13, no 4 [in Russian].

Löfgren, L. (1981). Life as an autolinguistic phenomenon. Autopoiesis: A Theory of Living Organization. M. Zeleny (Ed.). New York.

Narbut, N.P., Trotsuk, I.V. (2018a). The social well-being of the post-socialist countries' youth (on the example of Russia, Kazakhstan and Czech Republic): Comparative analysis of value orientations (Part 1). RUDN Journal of Sociology, vol 18, no 1 [in Russian].

Narbut, N.P., Trotsuk, I.V. (2018b). The social well-being of the post-socialist countries' youth (on the example of Russia, Kazakhstan and Czech Republic): Comparative analysis of fears and hopes (Part 2). RUDN Journal of Sociology, vol 18, no 2 [in Russian].

Martinelli, A. (2018). Sociology continues to be useful and even necessary. Monitoring of Public Opinion: Economic and Social Changes, no 5.

Mishutina, E.A. (2008). Happiness as an object of social-philosophical research. SocialHumanitarian Knowledge, no 10 [in Russian].

Rokeach, M. (1973). The Nature of Human Values. New York.

Rudnev, M.G. (2013). The invariant measurement of the basic values of the Russianspeaking population of four countries based on the Schwartz method. Sociology: $4 M$, vol 37 [in Russian].

Schwartz, S.H. (1992). Universals in the content and structure of values: Theoretical advances and 20 countries. Advances in Experimental Social Psychology, vol 25. M. Zanna (Ed.). New York.

Sontag, S. (2013). On Photography. Moscow: Garage [in Russian]

Turner, S.P. (2010). Explaining the Normative. Cambridge.

Veenhoven, R. (1991). Questions on happiness: Classical topics, modern answers, blind spots. Subjective Well-Being: An Interdisciplinary Perspective F. Strack, M. Argyle, N. Schwarz (Eds.). Oxford.

World Happiness Report (2018). J.F. Helliwell, R. Layard, J.D. Sachs (Eds.); J.-E. de Neve, Haifang Huang, Shun Wang (Ass. eds.). Available at: https://s3.amazonaws.com/ happiness-report/2018/WHR_web.pdf.

Zorin, A.L. (2016). The Uprise of the Hero: From the History of Russian Emotional Culture of the Late XVIII - Early XIX Century. Moscow [in Russian].

Превод на српски / Translation into Serbian

др Вера Вратуша / Vera Vratuša, $\mathrm{PhD}$ 